\title{
TRANSPORTATION OF DANGEROUS GOODS IN GREEN TRANSPORT CORRIDORS - CONCLUSIONS FROM BALTIC SEA REGION
}

\author{
Meike Schröder ${ }^{1}$, Gunnar Prause ${ }^{2}$ \\ ${ }^{I}$ Hamburg University of Technology \\ Institute of Business Logistics and General Management \\ Am Schwarzenberg-Campus 4, 21073 Hamburg, Germany \\ Meike.Schroeder@tuhh.de \\ ${ }^{2}$ Tallinn University of Technology \\ School of Economics and Business Administration \\ Akadeemia Tee 3, 12618 Tallinn, Estonia \\ Gunnar.Prause@ttu.ee
}

\begin{abstract}
The Green Corridor concept represents a cornerstone in the development and implementation of integrated and sustainable transport solutions based on trans-nationality, multi-modality and a high involvement of public and private stakeholders, including the political level. Despite the fact that the Green Transport Corridor (GTC) concept is founded on the three dimensions of sustainability with a strong emphasis on environmental aspects, the corridor hubs as well as the whole transport corridors have to find ways to handle and transport dangerous goods by keeping the high sustainability standards.

The paper addresses the research questions what kind of economical, ecological and social risks might occur in the context of handling and transportation of dangerous goods in a Green Transport Corridor in the Baltic Sea Region, what consequences they might have on the GTC design and how and with which measures they can be managed. Based on this analysis the development of a comprehensive risk management concept for the handling and transportation of dangerous goods in Green Transport Corridors in the Baltic Sea Region based on Schröder and Prause (2015) will be started. The concept will include practical implications and best practices.
\end{abstract}

Keywords: Green Transport Corridors, Dangerous Goods, Risk Management, Cases

\section{Introduction}

Green transport corridors (GTC) gain recently growing attention due to the need of transnational and sustainable transport solutions within European Union. The underlying motivation for the creation of GTC is the development of European transhipment route with concentration of freight traffic between major hubs and by relatively long distances of transport marked by reduced environmental and climate impact while increasing safety and efficiency with application of sustainable logistics solutions, intermodality, ICT-infrastructure, common and open legal regulations and strategically placed transhipment nodes. The theoretical foundations of GTC are related to sustainable aspects, multimodality, network and supply chain concepts (Hunke and Prause, 2013; Prause and Hunke, 2014).

But by following Schröder and Prause (2015) the implementation and management of a Green Transport Corridor is connected with a variety of risks due to the high level of complexity and the strong frame conditions of the concept so that stakeholders' violation of ecological and sustainable obligations might jeopardize the achievement of defined sustainability targets. Consequently, several scholars tried to propose different Key Performance Indicators (KPI) systems to monitor the corridor performance, to safeguard the compliance of GTC activities and to assess the risks (Hunke and Prause, 2013; Prause, 2014; Prause and Schröder, 2015; Schröder and Prause, 2015).

Within the GTC concept a crucial role is dedicated to the transhipment hubs usually represented by cargo terminals, ports or other logistics centres since these nodes often represent the bottlenecks and most vulnerable point in the transport network. Consequently, hub development measures require capital intensive infrastructural, legal and organizational decisions which are of strategic nature and heavily impact the GTC performance involving large groups of GTC stakeholder, especially hub owners, operators, customer interest groups and public bodies (Hunke and Prause, 2012). In the case of transportation of dangerous goods within the corridors the development and improvement of hubs are crucial for the GTC performance since the handling of dangerous goods is linked to specific requirements, often expensive and long-term infrastructural investments, due to strict regulations. 
The paper investigates the transport of dangerous goods in Baltic Sea Region (BSR) and discusses their impact on the GTC concept. Since the transportation and handling of dangerous goods are related to risks in the context of GTC the research questions of the paper are what kind of risks related to dangerous goods might occur in Green Transport Corridors what consequences they might have on the GTC design and how and with which measures they can be managed.

Based on conducted expert interviews and case studies during different EU projects in the Baltic Sea Region (BSR) (LogOn Baltic, EWTC II, C.A.S.H. and BSR Transport cluster) a comprehensive risk management concept in GTC had been developed (Schröder and Prause, 2015; Prause and Schröder, 2015). This is now supplemented by adding the transportation and handling of dangerous goods.

\section{Literature Review}

\subsection{Supply Chain Management and Green Transport Corridors}

Mentzer et al. (2001) argue that there are several definitions of Supply Chain Management (SCM) referring to the different conceptual perspectives on SCM versus logistics which have been evaluated during the last years. Some definitions contain operational activities involving the flow of materials and products, whereas others view it as a management philosophy or in terms of a management process (Tyndall et al., 1998). Christopher (1998, p.15) stresses the cooperation of supply chain partners as well as the importance of the customer and defines SCM as "the management of upstream and downstream relationships with suppliers and customers to deliver superior customer value at less cost to the supply chain as a whole". Stock and Lambert (2001, p. 54) point out the integration of tasks in their explanation: "SCM is the integration of key business processes from end user through original suppliers that provides products, services and information that add value for customers and other stakeholders."

In the following, the flow-oriented definition of logistics by the Council of Supply Chain Management Professionals (CSCMP) is used. It defines logistics as "the process of planning, implementing, and controlling procedures for the efficient and effective transportation and storage of goods including services and related information from the point of origin to the point of consumption for the purpose of conforming to customer requirement. This definition includes inbound, outbound, internal, and external movements (CSCMP 2015, p. 117).

In recent year there was a growing need for integrating environmental and sustainability aspects to SCM which led to research area of green supply chain management (GrSCM). Sarkis (2001) stressed the interdependency between conventional supply chain management and eco-programs in the context of green supply chain management whereas Hervani et al. (2005) emphasised the GrSCM practices - which include green purchasing, green manufacturing, materials management, green distribution/marketing and reverse logistics - refer to the involvement of environmental thinking into the SCM from the extraction of raw materials to product design, manufacturing processes, through to delivery of the final products to the consumers and end-of-life management (Srivastava, 2007). A special extension of green supply chains has been initiated by EU Commission in form of the green transport corridor (GTC) concept (FTLAP, 2007; COM, 2011) which can be characterized as European trans-shipment routes with concentration of freight traffic between major hubs and relatively long distances of transport marked by reduced environmental and climate impact, while increasing safety and efficiency with application of sustainable logistics solutions, inter-modality, information and communication technology infrastructure, common and open legal regulations and strategically placed trans-shipment nodes. The theoretical foundations of GTC are related to sustainable aspects, multimodality, network and supply chain concepts (Hunke and Prause, 2013; Prause and Hunke, 2014).

Since there are different interpretations of the main characteristics of GTC a number of international initiatives and concepts for Green Transportation Corridors have been developed, partly implemented and tested so far, in order to find a more practical approach to this issue. Most of the initiatives represent EU-funded regional development projects due to the political background of the Green Corridor concept with its links to the EU White Paper on Transport (COM, 2011). The Baltic Sea Region (BSR) became in recent years an important arena for sustainable transport projects since in several logistics projects on European and regional level aspects of green transportation have been studied in order to design more efficient and safe processes for multi-modal transport (BSR TC, 2013). All these projects highlight the efficient use of the available transport infrastructure, inter-modality and highperformance ICT-solutions together with intelligent transport systems as well as specific organisational frame conditions as main pillars for GTC (Prause and Hunke, 2014).

A major role for the performance and efficiency within the GTC concept is dedicated to the hubs along the routes of a transport corridor which are usually represented by cargo terminals, ports or other logistics centres since they often represent the bottlenecks for current or future transport demands. As Hunke and Prause (2012) pointed out the importance of these hubs or nodes is related to their functions as 
transhipment points along the corridors where cargo is "touched" and moved from one transport mode to another, is stored for a certain while or is even semi-manufactured or assembled. Since all these transhipment hub activities strongly influence the GTC efficiency the development and improvement of hub processes are crucial the GTC performance, especially in the context of handling of dangerous goods. But it has to be kept in mind that hub development is linked to infrastructural investments which requires large financial means and which is related to strategic GTC decisions.

Besides that, the implementations of GTC are still based on different understandings and realizations of the concept it is necessary to evaluate, compare and benchmark existing Green Corridor implementations. In this understanding the performance evaluation of GTC requires management control systems for supply chains comprising ecological aspects as well as the assessment of its international network environment by taking into account the international and cross-company aspects (Sydow and Möllering, 2009). Prause (2014) proposed a management control system in form of a Green Corridor balanced scorecard approach by integrating different sets of Key Performance Indicators (KPI) for monitoring and management of GTC as well as cooperative and network-oriented concepts from SCM. By following Prause and Schröder (2015) the current management control systems and existing KPI systems for GTC reveal an emphasis on sustainability and growth but they neglect risk issues which are related to the supply chain characteristics of a corridor.

\subsection{Risk Management for Green Transport Corridors}

Risks may have an influence on the flows of products, services, finance and information so that supply chain risk is "the damage - assessed by its probability of occurrence - that is caused by an event within a company, within its supply chain or its environment affecting the business processes of more than one company in the supply chain negatively" (Kersten et al., 2011a). Consequently, a lot of risks with a negative impact on the underlying supply chain or the touched hubs, especially those which are related to the transportation and handling of dangerous goods, may occur during the transport process, i.e. also within the multi-modal transportation chains within a GTC (Giunipero and Eltantawy, 2004). The multitude of actors integrated into transport services and GTC as well as their diversity even increases the number of potential risks.

To deepen the research of risks in the field of GTC the authors analysed case studies, expert interviews and workshops that have been conducted between 2006 and 2013 within several national and European projects comprising the BSR projects LogOn Baltic, EWTC II, C.A.S.H. and BSR Transport cluster to get a better understanding of the risks that might occur during transport services in general and in supply chains within GTC (Kersten et al., 2007 and 2011b; BSR TC, 2013). The surveys, interviews and workshops have been conducted by the authors during the European projects together with corridor managers, transport service providers, shippers and infrastructure providers.

In different interviews the experts were asked to name important transport risks to their company as well as risks that might occur in GTC. The interviewed experts primarily understand the term risk as a negative event which affects the company or the corridor itself. Hence, risk is seen as a threat to the success of the company and/or corridor and the company's and/or corridor's aims, respectively. Taking a bottom-up approach the risks were clustered in main categories describing the sources of risks (Schröder and Prause, 2015). The main categories were chosen in accordance with the three pillars of sustainability that are essential for the success of the GTC concept (Figure 1).

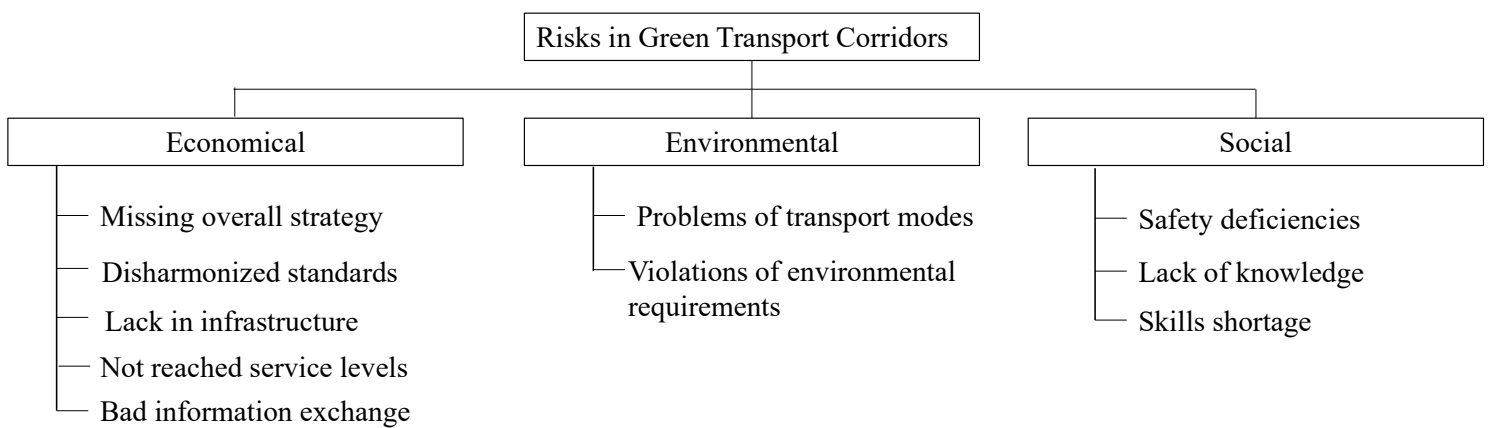

Figure 1. Main and subcategories of arising risks in Green Transport Corridors (Schröder and Prause, 2015, p. 233)

The first main category "economical aspects" incorporates five subcategories: "Missing overall strategy" (risks like a delayed implementation of the Green Transport Corridor concept due to a missing overall GTC logistics strategy or the risk of opportunistic behaviour), "Disharmonized standards"(Problems 
with country-specific border crossing, customs and different handling of police inspection), "Lack in infrastructure" (e.g. lack of warehouse and distributions centres, limited space available for port development), "Not reached service levels" (e.g. not reaching the predefined targets of total cargo volume, on-time delivery, relative transport costs, frequency, reliability or transit time) and "Bad information exchange"(risks like absence of information or bad information exchange among parties).

The second main category "environmental aspects" consists of two subcategories: "Problems of transport modes" (difficulties in resource planning, the non-optimal choice of transport routes, as well as long waiting times at transfer nodes of the corridor) and "Violations of environmental requirements" (causing a too big carbon foot print, not reached predefined targets regarding total energy use, greenhouse gases, $\mathrm{CO} 2$ emission, engine standards, etc.)

The third main category "social risks" was divided by the authors into three subcategories: "Safety deficiencies" (risks like not achieved social efficiency, different safety cultures in countries, regions and companies along the Green Transport Corridor, as well as a lack of experience which can lead to misinterpretation of driving dynamics resulting from different weather conditions within the BSR), "Lack of knowledge" (e.g. unknown safety regulations) and "Skills shortage" (shortage of qualified labour within the GTC regions in the BSR) (Schröder and Prause, 2015).

The implementation of the risk management concept depends heavily on the corridor management and on the governance concepts. Nevertheless, the transportation of dangerous goods and their related risks have been already in the focus of GTC projects. The East-West Transport Corridor Manual mentioned issues related to dangerous goods and integrated the international norm "ISO 9001 dangerous goods" into the EWTC2 Performance Indicators (EWTC, 2012; Hunke and Prause, 2013; see also Table 1). However, until now the transportation and handling of dangerous cargo in the GTC concept is neglected and its integration into the existing GTC management control systems has to be improved since ecological damages related to dangerous goods are threatening the greenness of GTC even more than in normal transport networks. But before the risk management concepts will be analysed against the background of transporting and handling dangerous goods in GTC, the transport of dangerous goods in BSR in general will be described, first.

\subsection{Transport of Dangerous Goods in BSR}

Dangerous goods or hazardous goods are solids, liquids, or gases that can harm people, other living organisms, property, or the environment and which usually include materials that are radioactive, flammable, explosive, corrosive, oxidizing, asphyxiating, biohazardous, toxic, pathogenic, or allergenic. Consequently, dangerous goods enjoy various regulations in case of transportation where the most important one is the "UN Recommendations on the Transport of Dangerous Goods" (UN, 2009 and 2011). Other, more specified regulations for air transport of dangerous goods exist from International Civil Aviation Organization (ICAO) which is based on UN Model as well as special regulations for maritime transportation of dangerous goods from International Maritime Organization (IMDG Code). Additionally, regulations for the International Carriage of dangerous goods by Rail (RID) exists. Finally, the Globally Harmonized System of Classification and Labelling of Chemicals (GHS) represent an international agreement for classification and labelling of dangerous goods in different countries (UNECE, 2011).

The UN Model divides dangerous goods into 9 classes according to hazards they pose, some of which are further subdivided into divisions. The 9 classes differentiate between explosives, gases, flammable liquids, flammable solids, oxidizing substances and organic peroxides, toxic substances and infectious substances, radioactive materials, corrosives and miscellaneous dangerous substances and articles (UN, 2009 and 2011). Additionally, the "Globally Harmonized System of Classification and Labelling of Chemicals" (GHS) was published in 2003 and concerns classification of dangerous goods together with harmonized hazard communication elements such as labels and safety data (UNECE, 2011). Important aims of GHS are to improve the protection of human safety, health and environment as well as to facilitate trade and transport of chemicals by providing a basis for harmonization of regulations on chemicals at various levels - national, regional and worldwide.

Special forms of transporting dangerous goods represent "general cargo" which includes beside containerized cargo also break bulk or packed cargo where the term "breakbulk" is often used to denote cargo that is loaded in unitized form such as pallets, bags, crates, boxes and bales; this form of transportation for dangerous goods is called packed dangerous goods (PDG) (Kendall and Buckley, 2001). Since packed dangerous goods can be categorised as general cargo shipments with PDG represent less than ship load, i.e. PGD shipments can appear in the context with other cargo or even with passengers. By following Mullai (2006) it can be stated that already the maritime transport of packed dangerous goods may be generally considered as statistically verifiable technological or human activity risks which require a sophisticated risk management which evidently also applies to dangerous goods transportation in GTC. 
The transportation of dangerous goods within BSR enjoys special regional regulations due to the specifics of the Baltic Sea (Mullai, 2006; Häkkinen, 2009). Important peculiarities of the BSR are their vulnerable eco-system, the high density of maritime traffic, the importance of ferry links and the high portion of oil products in maritime transportation. Hazardous substances can be transported either in bulk or packaged form. Bulked substances can be further divided into solids, liquids, and gases and those can be transported either by chemical carriers or by gas carriers (Hänninen and Rytkönen, 2006).

Consequently, the BSR countries of European Union agreed in 2006 on Memorandum of Understanding (MoU) for the Transport of Packaged Dangerous Goods in the Baltic Sea (BHS, 2015). In addition to that the already mentioned special regulations (ADR for road and RID for rail) for the land-based transportation of dangerous goods are completing the legal framework within BSR (UNECE, 2011; OTIF, 2016). Already these three main regulations for the transport of dangerous goods in the BSR deploy a crucial impact on the shipping and handling of hazardous cargo and by zooming into the three regulations it is possible to point out three important consequences for the transport of dangerous goods in the BSR:

- Restricted transport of dangerous goods through tunnels

- Restricted transport of dangerous goods with passenger ferries and ferries without open decks

- Need for specially trained and qualified personnel to handle and ship dangerous goods.

In the following chapter some cases will be introduced showing what kind of risks might occur when transporting and handling dangerous goods, based on the categorisation by Schröder and Prause (2015). It will be discussed what consequences they might have on the GTC design and how and with which measures they can be managed.

\section{Hotspots of Dangerous Goods in Baltic Sea Region}

By following Ots (2000) it can be assumed that more than $50 \%$ of bulk and $10-15 \%$ of containerized or packed cargoes transported by sea all over the world are classified as dangerous. About $45 \%$ of the volume of dangerous goods is related with oil or oil products whereas about $2 \%$ are representing chemicals. As Hänninen and Rytkönen (2006) pointed out oil products are also dominating by volume the dangerous cargo in BSR but due to high importance of ferry traffic in BSR the transport of important peculiarities of the BSR are their vulnerable eco-system, the high density of maritime traffic of hazardous substances in packed form enjoy a special importance in BSR.

The analysis of the statistics regarding the handling of containers within the port of the Baltic Sea has shown that the main European gateways for incoming dangerous goods into the BSR are the ports of Gdansk, Gothenburg and Hamburg (see Figure 2). They represent the BSR's main trans-shipment ports (Eurostat, 2016).

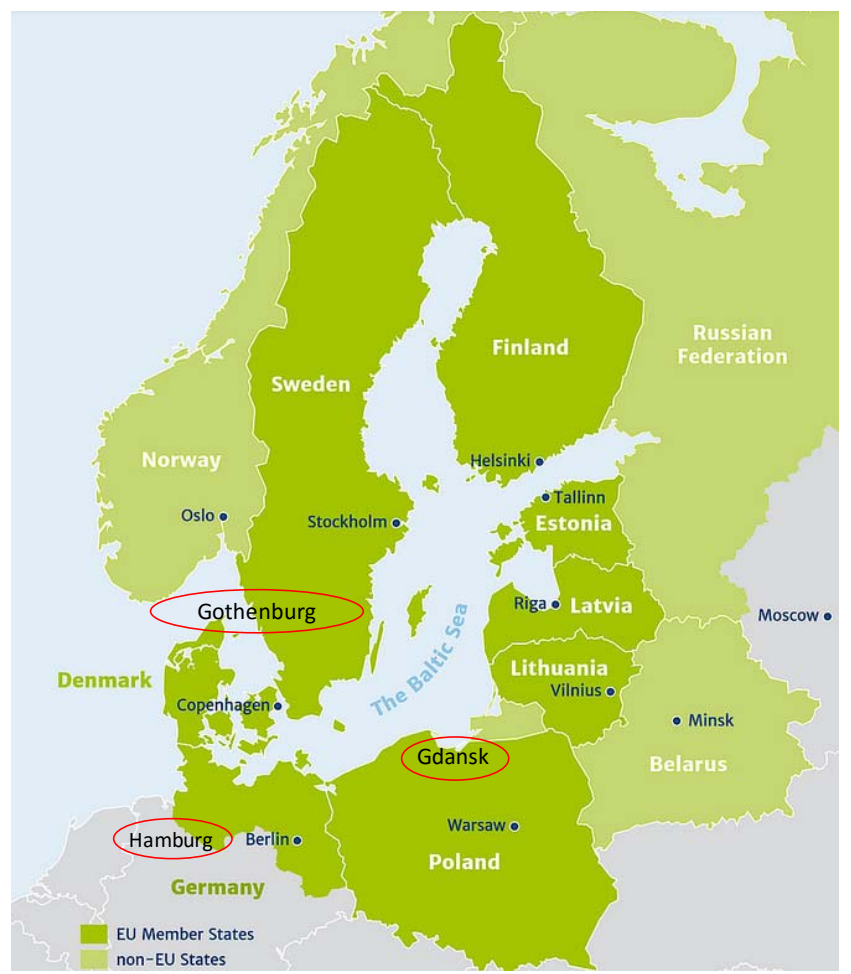

Figure 2. BSR's ports (of the EU member states) with direct shipping connections to/from China (sources: Eurostat, 2016, Interreg, 2016) 
They all have direct international shipping connections to and from China and therefore are initial contact points for cargo loaded with dangerous good made in China. This cargo is then distributed by feeder ships, by trucks or by railways over the whole Baltic Sea Region.

Ots (2000) furthermore identified 130 shipping routes in the BSR carrying dangerous goods where only in 80 of them monthly quantities are bigger than 100 tonnes. The highest traffic density is in the southern part of the Baltic Sea, near the Kiel Canal approach and its surrounding waters. A medium traffic density is found in Danish waters, the Kattegat, along the Swedish east coast and in the Gulf of Finland. The most important Baltic ports concerning the transportation of packed dangerous goods with a value of more than 10000 tons per month are Gdansk in Poland, Gothenburg in Sweden and Nyborg in Denmark (Ots, 2000, Annex 3). This statistics also reveal that at least for Gdansk and Gothenburg to counterparts for transportation are situated outside Baltic Sea.

The main handling and transhipment points for dangerous goods in BSR are not equally distributed but rather concentrated in hotspots with large handling volume and transregional importance. The biggest BSR port by volume is the Russian oil port of Primorsk. By following Stankiewicz et al. (2010) the total volume of transported oil products in BSR accounts for 170 million tons per year where only the export of Russian oil through the Baltic ports currently reaches a level of about 120 million tonnes and it is expected to reach 180 million tonnes in 2020. But Luhtala (2010) pointed out that also the transportation of chemicals in BSR has to be considered in the context of dangerous goods because this cargo accounts for about 9 million tons per year.

In addition to that, the transportation of packed dangerous goods plays an important role due to the domination of roro - ferry operations in the internal BSR maritime traffic. Ots (2000) identified the total quantity and number of parcels of transported dangerous in the Baltic Sea and found out that about 150000 tons of dangerous goods in about 11000 parcels were transported by BSR ferry lines where about half of the total dangerous cargo was shipped on only 34 different routes. Among the list of ports which are handling the PDG cargo appear nearly all important BSR ports including, Copenhagen, Helsinki, Stockholm and Tallinn.

\section{Cases and Experiences}

\subsection{Accidents During the Transport of Dangerous Goods}

The transportation and handling of dangerous goods is related with a lot of risks and additional costs. One important area of risks is linked to accidents which touch all parts of the multimodal supply chain. The analysis of literature and different statistics has shown that during the last decade accidents with dangerous goods have caused the death of many civilians and left many more injured. Schröder and Prause (2016) gave a list of striking accidents during the transportation of dangerous goods for different modes of transport. This list comprises a gas explosion at the Port of Duisburg (Germany) in March 2016 or a series of explosions at the port of Tianjin (China) in August 2015, a fire on the German container ship MSC Flaminia due to misdeclared cargo consisting of dangerous goods in July 2012, a violent explosion and a large fire in September 2002 of two freight trains in Bad Münder (Germany) where one train loaded with epichlorhydrin or a similar accident happened 2009 in Viareggio (Italy) when a freight train loaded with liquefied gas derailed (Handelsblatt, 2016; The Guardian, 2015; Die Zeit Online, 2012; Eisenbahn-Bundesamt, 2004; Spiegel, 1999). More often and common in daily news are road accidents like the fire in the Tauern Road Tunnel (Austria) in May 1999 of a truck that loaded 24.000 doses of spray paints and was engaged in a collision with other vehicles waiting for a traffic signal.

The examples of dangerous goods accidents show that their consequences can be very different, but their origins (based on misdeclared or unsecured cargo or due to human failings) can be transferred to nearly each geographical region in the BSR. The accident in Tianjin has emphasized the importance of right declared dangerous goods as well as the risk of bad information exchange and communication between companies and rescue services, once more (see Figure 1). Due to the fact that the fire brigade did not know what kind of dangerous goods was stored in the warehouse they tried to extinguish the fire with water. But chemicals like sodium cyanide releases flammable gas when contacting with water and therefore, caused a violent explosion, in this case. As a consequence, many firefighters died (The Guardian, 2015).

Although a high number of containers is classified as containing dangerous goods, the experiences show that a substantial number of containers contains non-declared dangerous goods, increasing the risk of safety deficiencies (see Figure 1). 
A best practice example to detect incorrectly declared dangerous goods was developed by the German-Chilean transportation company Hapag-Lloyd that comprises a cargo container shipping line (Hapag Lloyd, 2016). With the help of the so-called "watchdog software" the company continuously examines the data of all cargo transported worldwide to identify conspicuous terms and word combinations. The software processes more than 6000 key words and inspects the shipping documents. Whenever dissent emerges "the watchdog barks" (162.000 times in 2014) and leads the information further to the dangerous goods experts. They then look at each consignment and investigate it. By using the software in 2014 Hapag Lloyd had prevented that more than 4.000 containers with wrong or not declared dangerous goods worldwide could have been transported by their ships. Therefore, they reduced the hazard potential especially for crew members, ships and environment. This invention should not only be applied to shipping lines entering harbours in the BSR, it should also be applied to stakeholders being involved in the inspection and transport process of dangerous goods, as there are police and port authorities, consignor or logistics service providers.

Another best practice example for inspections of containers is located at Muuga (Tallinn). Two years ago the company that operates Muuga container terminal in Tallinn (Transiidikeskuse), has implemented a completely automated and electronic container inspection system (GreenCarrier, 2015). By scanning all entering and outgoing containers passing through the terminal any possible damage or defect on the cargo is detected by the system and reported into a stock keeping program. Compared to terminals using a person on the pier, inspecting the cargo, the container inspection system in Muuga is more secure, reliable and faster and it reduces the risk of injuries in the port at the same time.

\subsection{Risks from Disharmonized Standards}

Another economical risk results from disharmonized standards (see Figure 1). Although dangerous goods transport is subject to international conventions for each mode (sea, road, rail) operational practices about inspections on the one hand, and load security of dangerous goods on the other hand vary between the countries. For this reason, the inspection processes within the GCT should be harmonized within the Supply Chain: starting from cargo discharging in the harbour (or even from the point of origin in China, India or South America) and ending at the final destination in the BSR. A harmonization of the inspection process can e.g. be achieved by organizing international joint excursions among the different inspection authorities. By involving inspection authorities form the point of origin who are responsible for the outgoing cargo loaded with dangerous goods, the number of not or wrong declared dangerous goods finding their way to the BSR will be reduced. For this reason, a proactive risk management approach for the entire supply chain of dangerous goods should be aimed for.

Not only inspection authorities should be well-educated, but also the employees involved in the loading and transport process of dangerous goods. Only by offering professional trainings regarding the storage, cargo securing and cargo transport of dangerous goods risks regarding lack of dangerous goods knowledge can be avoided and a high safety standard can be achieved (see Figure 1). Each employee involved in these processes must be aware of possible negative consequences an accident with dangerous goods can have. Therefore, companies should ensure that their employees fulfil the requirements for their occupational group (e.g. dangerous goods safety advisor, ADR certificate) and that they know the requirements on handling of dangerous goods as well as current safety standards. In addition, companies should invest into further education for dangerous goods.

At the same time, the information exchange between the companies, inspection authorities and rescue services in the GTC should be improved, as it could have been seen at the negative example of Tianjin. Due to the fact that the GTC runs through several countries, country-specific reporting systems must be known and different IT interfaces must be overcome. Therefore, the reporting systems and processes should be harmonized and be easy to apply to counteract the bad information exchange (see Figure 1).

\subsection{Additional Infrastructural Costs due to Dangerous Goods}

A very important and expensive impact of the transportation of dangerous goods is related to infrastructural topics. The above mentioned accident with dangerous goods at the Tauern Road Tunnel caused a tightening up of the existing legislation towards a regulation that tunnels have been categorised (B-E) and for road tunnel safety-related issues the thoroughfare for trucks was becoming severely restricted. But in a consequence the new legislative leads to additional costs and time consumption for logistics operations as well as to new requirements for the construction of infrastructure. In the case of Hamburg (Germany) this means that trucks loaded with dangerous goods are not allowed to pass the Elbtunnel (one of the longest road tunnels underwater in the world) between 5 a.m. and 11 p.m.; they 
have to take alternative routes which causes longer transport time and additional cost due to detours (Schröder and Prause, 2016).

In the case of Tallinn which is the final land-based station of the planned "Rail Baltica" project of the European Union the transportation of dangerous goods even forces new investments. "Rail Baltica" is a project of the EU transport policy aiming to build core network corridors which represent the strategic heart of the trans-European transport network (TEN-T). Around the "Rail Baltica" activities the EU project "Rail Baltica Growth Corridor" supported the development of "Rail Baltica" towards a green transport corridor concept for mixed transportation of passengers and cargo by integrating Helsinki as an additional station via a short sea shipping approach (Beim and Majewski, 2012; Keinänen and Paajanen, 2013). Risk avoiding and security improvement potential of the investment around "Rail Baltica" were discussed but not in the context of the transportation of dangerous goods (Hilmola, 2016). But the situation in Tallinn shows that the transportation of dangerous goods can play an important role for infrastructural decisions in GTCs.

One main objective of the implementation of "Rail Baltica" project is the connection of the Baltic States to the European railway system since the Baltic States railways are still running on the Russian tracks which are not compatible with the European gauge (Keinänen and Paajanen, 2013). When in the near future the European tracks are installed till the final Rail Baltica Station in Tallinn it has to be decided in order to fulfil the concept of the "Rail Baltica Growth Corridor" how to continue to Helsinki which has to be done by short sea shipping due to the Finish Gulf between Estonia and Finland. Until now, two ports are existing already in Tallinn for this purpose, the ferry port in the city centre of Tallinn and the cargo port in Muuga, east of Tallinn (Beim and Majewski, 2012; Keinänen and Paajanen, 2013). The ferry operations between Helsinki and Tallinn are realised by fully closed RoPax ferries whereas the cargo shipping between Tallinn and Helsinki is operated by ships without passengers.

By following the rules of the Memorandum of Understanding for the Transport of Packaged Dangerous Goods in the Baltic Sea it is inevitable to ship certain dangerous goods like flammable or toxic gases (including LNG), organic peroxides or toxic substances even in packed form via Muuga (BHS 2015). Consequently, the continuation from Rail Baltica Station in Tallinn requires two linkages to Port of Tallinn as well as to Muuga causing expensive additional infrastructure costs. This case leads to the additional consideration that along the Rail Baltica some of the main hubs are placed inside cities like in Tallinn, Riga or Kaunas in order to be convenient for rail passengers so that the transportation of dangerous goods along the "Rail Baltica" makes it necessary to plan and construct railway bypasses to keep risks out of urban areas.

Transferring this example to the transport of dangerous goods in GTC in the BSR the long distances must be checked regarding areas that do not permit the transport of dangerous goods (e.g. due to long tunnels, narrow roads or high population densities) and alternative routes must be provided. Not only alternative routes must be offered, but also an intelligent truck parking system and safe and wellilluminated parking areas must be established. Furthermore, Warehouses, distribution centres and harbour areas must fulfil the international requirements on storing dangerous goods to avoid the risk of lack in infrastructure (see Figure 1).

On the one hand this is linked to additional infrastructure costs along the GCT, on the other hand, as mentioned before, the hubs along the routes of a transport corridor which are usually represented by cargo terminals, ports or other logistics centres, are essential for the performance and efficiency within the GTC. Against this background the risk of a missing overall strategy might even be intensified in the field of dangerous goods transportation (see Figure 1).

Another development that must be considered when elaborating and adopting an overall GTC logistics strategy is that LNG (Liquefied Natural Gas) is becoming of increasing importance as a fuel in shipping - also in the BSR. The infrastructure (road, rail and sea) for providing ships with extremely flammable LNG must be ensured and secured. Thereby, the harbour area is the point where the different transport modes meet (Mullai, 2006, p. 44).

The overall strategy for GTC, including e.g. the routes of the corridor, location and capacity planning of transportation hubs, warehouses and parking areas) is becoming even more complex, but also more important when it comes to the transport of dangerous goods (see Figure 1). The necessity for network-oriented management control systems for GTC as well as the introduction of KPI on company and mainly on upper (e.g. regional of country) level, is increasing.

\section{Risk of Dangerous Goods in GTC Management Control System}

First attempts to integrate risk aspects into a GTC management control system have been started by Prause (2014) by proposing a green transport corridor balanced scorecard and by Prause and Schröder 
(2015) who suggested KPI building blocks for GTC. Both approaches are flexible, scalable and adaptable to the special needs of a specific transport corridor and they are an extension of the KPI system for multimodal sustainable transport that has been developed by the consortium of the EU-funded project "EastWest-Transport-Corridor (EWTC2)" and which has been described in the "Green Corridor Manual" (EWTC, 2012; Hunke and Prause, 2013; Table 1).

This KPI set separates into two subsets of indicators measuring enabling and operational criteria. In the context of the transport of dangerous goods the currently discussed KPI sets are not completed since risk indicators are still missing (Prause and Schröder, 2015). New KPI for dangerous goods should be adapted to the existing enabling and operational indicators.

In Table 1 the EWTC2 Performance Indicators are suggested to control the performance of handling dangerous goods in GTC. They are allocated concerning the economic, environmental and social efficiency. As operational indicators for economic efficiency the total cargo volume and number of transports on different corridor sections could be measured regarding the categories of hazardous goods (GHS). The corridor capacity offering alternative routes due to restricted areas or the number of hub which are restricted for transport and handling of special categories of hazardous goods could e.g. be enabling indicators. Regarding the environmental efficiency, the number of dangerous goods transportation incidents, ISO 9001 or the Memorandum of understanding for the transport of packages dangerous goods in the Baltic Sea could be operational indicators (BHS, 2015). As enabling indicators the number of filling stations for LNG, or the number of security checks operated by inspection authorities could be listed. Furthermore, the number of dangerous goods safety adviser as well as the number of ADR training certificates could be operational indicators in the field of social efficiency. The number of secured and well-illuminated parking areas considering dangerous goods requirements or the number of conferences in the field of dangerous goods could be helpful enabling indicators.

Table 1. EWTC2 Performance Indicators supplemented regarding the transport and handling of dangerous goods

\begin{tabular}{|c|c|c|}
\hline $\begin{array}{l}\text { Performance } \\
\text { areas }\end{array}$ & Operational indicators & Enabling indicators \\
\hline $\begin{array}{l}\text { Economic } \\
\text { efficiency }\end{array}$ & $\begin{array}{l}\text { - Total cargo volumes and number of transports on } \\
\text { different corridor sections classified regarding the } \\
\text { categories of hazardous goods (GHS): explosives, } \\
\text { gases, flammable liquids, flammable solid, } \\
\text { radioactive substances, etc. } \\
\text { - Number of restricted areas (long tunnels, densely } \\
\text { populated areas, nature conservation areas, etc.) } \\
\text { - Number of required licences for transportation of } \\
\text { DG } \\
\text { - Transit and handling time of DG [hours]; } \\
\text { (departure and arrival time) }\end{array}$ & $\begin{array}{l}\text { - Corridor capacity (offering alternative routes due } \\
\text { to restricted areas) } \\
\text { - Number of hubs restricted for the transport and } \\
\text { handling of dangerous goods } \\
\text { - Number of facilities and aids for loading safety }\end{array}$ \\
\hline $\begin{array}{l}\text { Environmental } \\
\text { efficiency }\end{array}$ & $\begin{array}{l}\text { - Number of DG transportation incidents } \\
\text { - Total energy use (total number of vehicles/vessels } \\
\text { in use) } \\
\text { - Greenhouse gases, CO2e } \\
\text { - Engine Standards } \\
\text { - ISO } 9001 \text { dangerous goods } \\
\text { - UN Recommendation of the Transport of } \\
\text { Dangerous Goods (2009, 2011) } \\
\text { - Memorandum of understanding (MoU) for the } \\
\text { Transport of Packaged Dangerous Goods in the } \\
\text { Baltic Sea (BHS 2015) }\end{array}$ & $\begin{array}{l}\text { - Number of alternative fuels filling stations for } \\
\text { LNG } \\
\text { - Number of security checks operated by } \\
\text { inspection authorities (e.g. check for leaks, } \\
\text { adequate ventilation, radiation measuring, cargo } \\
\text { securing and labelling of dangerous goods) } \\
\text { - Number of weather stations for submitting data } \\
\text { of weather conditions for DG transports }\end{array}$ \\
\hline $\begin{array}{l}\text { Social } \\
\text { efficiency }\end{array}$ & $\begin{array}{l}\text { - ISO } 31000 \\
\text { - } \text { ISO } 39000 \\
\text { - Number of dangerous goods safety adviser } \\
\text { - Number of ADR training certificates }\end{array}$ & $\begin{array}{l}\text { - Number of secured and well-illuminated parking } \\
\text { areas } \\
\text { - Number of DG conferences and seminar, joint } \\
\text { excursions between inspection authorities } \\
\text { offered within GTC } \\
\text { - Number of offered further education per } \\
\text { company } \\
\text { - Common safety rating } \\
\text { - Fenced terminals }\end{array}$ \\
\hline
\end{tabular}

But even if all data would be available and aggregation procedures for calculating corridor indicators would be feasible a problem of delimitation still exists, since a GTC integrates different stakeholders along a certain limited geographical area. Logistics services between destinations outside the 
corridor which are using only parts of the corridor have to be taken into account for performance assessments. Therefore, it will be a high challenge to build a steering committee for different corridor sections and to collect and aggregate KPI on a corridor level, especially those considering dangerous goods-related data. But to increase the safety standard in GTC and to reduce several risk potentials it is indispensable. By following Lukinskiy et al. (2013) a big step ahead would be the development of a methodology and tools for assessment of efficiency of logistical infrastructure.

In addition, the KPI set could be completed with a corridor dashboard in order to connect the short-term KPIs and the enabling KPIs by visualizing capacity, accessibility and performance (Prause, 2014). An important characteristic of the dashboard is its hub-orientation, i.e. that the dashboard depicts the main characteristics of the corridor hubs together with their infrastructural links (EWTC, 2012).

As part of the ongoing development of the dashboard, which was developed in the EWCT project, Figure 3 shows a possible extension.

The dashboard visualises the modes of transport between the different hubs by which dangerous goods can be transported. E.g. form hub A to hub B goods can only be transported by road. In the case of dangerous goods transport is it not allowed to handle any radioactive material in this corridor section. Another part of the dashboard shows where alternative routes for the dangerous goods transport are necessary. E.g. due to some long tunnels an alternative route from hub $\mathrm{B}$ to hub $\mathrm{C}$ for some road and railway sections must be organized.

A third part of the dashboard visualizes the available secured and well-illuminated paring areas, or whether LGN filling stations are available or not. As it can be seen in Figure 3, there are no parking areas in hub $\mathrm{A}$ and $\mathrm{E}$ available which considering the requirements on dangerous goods.

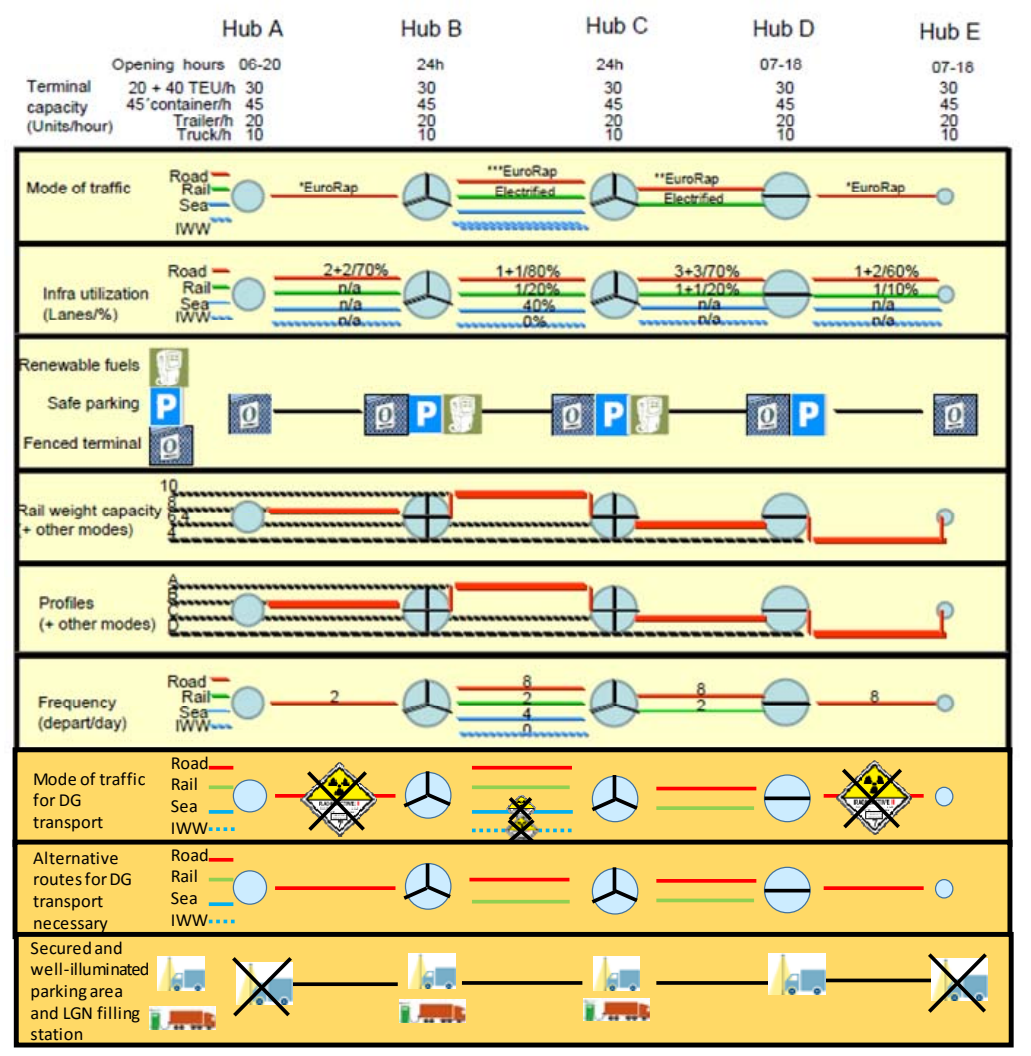

Figure 3. Dashboard supplemented by aspects of transporting dangerous goods

Under this consideration a dashboard represents a simple labelling system for the underlying green transport corridor infrastructure by linking and visualising relevant KPIs for operational control with enabling factors comprising capacity, redundancy and performance. But the extended dashboard according to the needs for the transportation of dangerous goods is necessary in order to solve routings for dangerous goods through the GTC. It also reveals infrastructural bottlenecks in the corridor related to the transportation of dangerous goods. 


\section{Conclusion}

The GTC is imbedded into an international network environment composed of different stakeholders acting along a defined geographical area in order to achieve their different goals within the frame of common corridor objectives. The shipping and handling of dangerous goods is related to strict regulations and risks which have to be taken into account when implementing and managing GTC, especially in the BSR due to specific additional regulations.

An important role for the performance of GTC is dedicated to their transhipment hubs so that the improvement and development of these corridors nodes represents a crucial and expensive task since hub decisions are often infrastructural and strategic. The special requirements and frame conditions on handling, storing and transporting dangerous goods in the BSR even increase the number and kind of possible risks that might occur in GTC. Therefore, the different risks should be considered when developing the overall GTC strategy and they should be integrated into GTC management control systems.

The paper analysed and discussed cases and conclusions from BSR and highlighted their impact on KPI-sets since until now risk indicators in the context of the transportation of dangerous goods are neglected in the management of GTC. The impact of transportation of dangerous goods vary from operational level including additional time and costs to strategical level touching infrastructure, legislation and workforce qualification. One possibility to implement a holistic GTC management control instrument is the further development of a KPI-system considering economic, environmental and social efficiency or the further development of the corridor dashboards, both extended by dangerous goods issues. These extensions are necessary to find routings of dangerous goods through the GTC and to identify infrastructural weaknesses within the corridor which have to be mitigated to safeguard an appropriate flow for all kind of cargo through the corridor as well as a sustainable corridor development. Further research has to done in order to generate concepts and measures for hub development in GTCs reacting on the impact of dangerous goods transportation.

Reference (German titles translated by the authors)

1. Beim, M. and Majewski, J. (2012) Rail Baltica Growth Corridor - WP4: Final Report, Available on (15/08/2016) at: http:/www.rbgc.eu/media/articles/final-report-wp4.pdf.

2. BSH (2015) Notification of MoU for the Transport of Packaged Dangerous Goods on Ro-Ro Ships in the Baltic Sea, Available on (03/08/2016) at: http://www.bsh.de/de/Schifffahrt/ Sportschifffahrt/Berichtigungsservice_NfS/Schifffahrtsvorschriften/2015/Beilage04-2015.pdf.

3. BSR TC (2013) BSR Transport Cluster - for sustainable, multimodal \& green transport corridors, Available on (20/06/2015) at: http://transportcluster.eu/.

4. COM (2011) Roadmap to a Single European Transport Area - Towards a competitive and resource efficient transport system. Commission of European Communities. Brussels, 28.03.2011.

5. Christopher, M. (1998) Logistics and Supply Chain Management: Strategies for reducing cost and improving service. London u.a.: Financial Times Prentice Hall.

6. CSCMP - Council of Supply Chain Management Professionals. (2015) Glossary of terms - logistics, Available on (03/08/2016) at: https://cscmp.org/research/glossary-terms, p. 117.

7. Die Zeit Online (2012) The MSC Flaminia, Available on (03/08/2016) at http://www.zeit.de/wissen/umwelt/2012-08/flaminia-havarie.

8. Eisenbahn-Bundesamt (2004) Examination Report of the accident at the train station in Bad Münder, published by the German Railway Agency.

9. Eurostat (2016) Statistics, Available on (17/08/2016) at: http://ec.europa.eu/eurostat/de/data/browsestatistics-by-theme.

10. EWTC (2012) Green Corridor Manual - Task 3B of the EWTC II project, Available on (20/06/2015) at: http://www.ewtc2.eu/media/310370/ewtcii_manual_lowres.pdf.

11. FTLAP (2007) Communication from the Commission: Freight Transport Logistics Action Plan. Commission of European Communities. Brussels, 18.10.2007.

12. Giunipero, L.C. and Eltantawy, R.A. (2004) Securing the upstream supply chain: a risk management approach. International Journal of Physical Distribution \& Logistics Management, 34(9), 698-713. DOI 10.1108/09600030410567478.

13. GreenCarrier (2015) The first automated container inspection system in the world, Available on (03/08/2016) at: http://blog.greencarrier.com/the-first-automated-container-inspection-system-in-theworld/. 
14. Handelsblatt (2016) Explosion on a tankship, Available on (03/08/2016) at: http://www.handelsblatt.com/panorama/aus-aller-welt/duisburger-hafen-tote-nach-explosion-auftankschiff/13384620.html.

15. Häkkinen A. (2009) Vaarallistenaineidenkuljetukset 2007. Viisivuotisselvitys. (Transport of dangerous goods in 2007, five-year report). Available on (03/08/2016) at: http://www.lvm.fi/web/fi/julkaisu/view/930311.

16. Hänninen, S. and Rytkönen, J. (2006) Transportation of liquid bulk chemicals by tankers in the Baltic Sea. Technical Research Centre of Finland., Finland. Available on (02/08/2016) at: http://www.vtt.fi/inf/pdf/publications/2006/P595.pdf.

17. Hapag Lloyd (2016) Watchdog, Available on (02/08/2016) at: https://www.hapag-lloyd.de/de/products/cargo/dg/cargo-patrol.html.

18. Hervani A.A., Helms, M.M. and Sarkis, J. (2005) Performance measurement for green supply chain management. Benchmarking: An International Journal, 12 (4), 330-353. DOI 10.1108/14635770510609015.

19. Hilmola, O.P. (2016) Security Improvement Potential of Rail Baltica Investment. In: Szyliowicz et al. (eds.) Multimodal Transport Security: Frameworks and Policy Applications in Freight and Passenger Transportation. Cheltenham, UK: Edgar Elgar Publishing, 107-123.

20. Hunke, K. and Prause, G. (2012) Hub Development along Green Transport Corridors in Baltic Sea Region. Blecker, T. and Kersten, W. and Ringle, C. (eds.). Pioneering Supply Chain Design, Lohmar et al.: EUL.

21. Hunke, K. and Prause, G. (2013) Management of Green Corridor Performance. Transport and Telecommunication, 14(4), 292-299. DOI 10.2478/ttj-2013-0025.

22. Interreg (2016) Baltic Sea Region. Available on (15/08/2016) at https://www.interreg-baltic.eu/aboutthe-programme/programme-area.html.

23. Keinänen, O. and Paajanen, M. (2013) Rail Baltica Growth Strategy. Available on (15/08/2016) at: http://www.rbgc.eu/media/rail-baltica-growth-strategy-version-1.1.pdf.

24. Kendall L.C. and Buckley J.J. (2001) The Business of Shipping. Centreville, Md: Cornell Maritime Press.

25. Kersten, W., Hohrath, P., Böger, M. and Singer, C. (2011a) A Supply Chain Risk Management Process. International Journal of Logistics Systems and Management, 8(2), 152-166, DOI 10.1504/IJLSM.2011.0386.

26. Kersten, W., Böger, M., Schröder, M. and Singer, C. (2007) Developing Regions through Spatial Planning and Logistics \& ICT competence - Final report, as part of the publication series of the EU project LogOn Baltic, LogOn Baltic reports, 1:2007.

27. Kersten, W., Schröder, M., Singer, C. and Feser, M. (2011b) Analysis of Transport Risks - Empirical Results from the Baltic Sea Region in 2010/2011. C.A.S.H. report 3:2011.

28. Luhtala, H. (2010) Maritime transport of chemicals in the Baltic Sea, Centre for maritime studies, University of Turku, Finland.

29. Lukinskiy, V.S., Pimonenko, M.M., Paajanen, M. and Shulzhenko, T.G. (2013) Development of Methodology and Tools for comparative Assessment of operational Efficiency of KPI-based logistical Infrastructure Facilities, Transport and Telecommunication, 14(3), 223-229, DOI 10.2478/ttj-2013-0019.

30. Mentzer, J., DeWitt, W., Keebler, J., Min, S., Nix, N., Smith, C. and Zacharia, Z. (2001) Defining Supply Chain Management, Journal of Business Logistics 22(2); 1-25, DOI 10.1002/j.21581592.2001.tb00001.x.

31. Mullai, A. (2006) Maritime Transport and risk of package dangerous goods, DaGoB Publication Series 4:2006, Turku School of Economics.

32. OTIF (2016) Intergovernmental Organisation for International Carriage by Rail: Basic ConventionCOTIF \& Appendix C-RID, Berne, Available on (02/08/2016) at: http://www.otif.org.

33. Ots, T. (2000) Transport and handling of dangerous cargoes in port areas: weaknesses of existing international and Estonian regulations, World Maritime University Dissertations, Paper 243.

34. Prause, G. (2014) A Green Corridor Balanced Scorecard. Transport and Telecommunication, 15(4), 299-307. DOI 10.2478/ttj-2014-0026.

35. Prause, G. and Hunke, K. (2014) Secure and Sustainable Supply Chain Management: Integrated ICTSystems for Green Transport Corridors. Journal of Security and Sustainability Issues, 3(4), 5-16. DOI 10.9770/jssi.2014.3.4(1).

36. Prause, G. and Schröder, M. (2015) KPI Building Blocks for Successful Green Transport Corridor Implementation. Transport and Telecommunication, 16 (4), 277-287, DOI 10.1515/ttj-2015-0025. 
37. Sarkis, J. (2001) Introduction. Greener Management International, 35(3), 21-25.

38. Schröder, M. and Prause, G. (2015) Risk management for green transport corridors. Journal of Security and Sustainability Issues, 5 (2), 229-239, DOI 10.9770/jssi.2015.5.2(8).

39. Schröder, M. and Prause, G. (2016) Dangerous goods transportation in green transport corridors in the Baltic Sea Region - Cases and Recommendations. Proceedings of the 16th International Conference "Reliability and Statistics in Transportation and Communication" (RelStat'16), 19-22 October 2016, Riga, Latvia, 149-157, ISBN 978-9984-818-83-2.

40. Spiegel. (1999) Fire in the Tauern Road Tunnel, Available on (02/08/2016) at http://www.spiegel.de/panorama/tauerntunnel-brand-unter-kontrolle-a-24943.html.

41. Srivastava, S. (2007) Green Supply Chain Management: A state-of-the-art literature review, Intl. Journal of Management Reviews, 9(1), 53-80, DOI 10.1111/j.1468-2370.2007.00202.x.

42. Stankiewicz, M., Backer, H. and Vlasov, N. (2010) Maritime Activities in the Baltic Sea - An integrated thematic assessment on maritime activities and response to pollution at sea in the Baltic Sea Region. HELCOM Baltic Sea Environment Proceedings No. 123.

43. Stock, J.R. and Lambert, D.M. (2001) Strategic Logistics Management. Boston: McGraw-Hill.

44. Sydow, J. and Möllering, G. (2009) Production in networks, $2^{\text {nd }}$ ed., Munich: Franz Vahlen.

45. The Guardian (2015) Tianjin explosion: China sets final death toll at 173, ending search for survivors, Available on (03/08/2016) at: https://www.theguardian.com/world/2015/sep/12/tianjinexplosion-china-sets-final-death-toll-at-173-ending-search-for-survivors.

46. Tyndall, G., Gopal, C., Partsch, W. and Kamauff, J. (1998) Supercharging Supply Chains: New Ways to Increase Value Through Global Operational Excellence. New York: John Wiley \& Sons.

47. UN. (2009) Recommendations on the transport of dangerous goods. Model Regulations, 16th edition, Geneva.

48. UN (2011) Economic and Social Council: Economic Commission for Europe: Inland Transport Committee: Report of the Inland Transport Committee on its seventy-third session, Seventy-third session, Geneva.

49. Unece (2011) Globally harmonized system of classification and labelling of chemicals $(G H S), 4^{\text {th }} \mathrm{ed}$. Geneva, New York. Available on (27/07/2016), at https://www.unece.org/fileadmin/DAM/trans/ danger/publi/ghs/ghs_rev04/English/ST-SG-AC10-30-Rev4e.pdf. 